\title{
A Start up Socially Responsible Subject of Evolutionary Change in Its Sector
}

\author{
Maria Fedele ${ }^{1}$ \\ ${ }^{1}$ Dept. of Economics and Law, University of Cassino and Southern Lazio, Cassino, Italy \\ Correspondence: Maria Fedele, Dept. of Economics and Law, University of Cassino and Southern Lazio, \\ Cassino, Italy. Tel: 393-473-113-751. E-mail: m.fedelecam@libero.it
}

Received: February 28, 2015

Accepted: March 9, 2015

Online Published: April 20, 2015

doi:10.5539/ijbm.v10n5p57

URL: http://dx.doi.org/10.5539/ijbm.v10n5p57

\begin{abstract}
This research aims to verify, through a case study, if a firm operating in a sector plagued by the crisis can successfully overcome the start-up phase by creating shared value with stakeholders, supporting and anticipating the trends of its reference environment. The study of the choices that have enabled the company to establish itself and its results, if consistent with the assertions of the literature, will, therefore, allow to validate the thesis and to measure the effectiveness of the theories and observations cited. The originality of the work lies in the proposed case study: a company that, since the start-up phase, every day "listening" to the needs of the market, and thanks to the propensity to technological innovation in addition to dimensional growth both nationally and internationally, has been at the center of the transformation processes in its industry, rather than be guided by it. All associated with the voluntary adoption of structural and organizational, production and communication models that enable the social responsibility of the Renner Italy SPA to generate values and not just profits.
\end{abstract}

Keywords: value creation, stakeholder's theory, evolutionary change, corporate social responsibility, innovation, interactions, ethical values

\section{Introduction}

The current economic and social context, characterized by rapid, intense and multi-directional change (Paci, 2003), requires the company to perform well its social function, thus overcoming the conception of the company as a mechanical system, capable of operate independently of the stimuli from the external environment. Today, in fact, it is considered as a viable system which can survive only if it can satisfy the interests of internal and external parties which put expectations on it (Golinelli, 2005). The company must, therefore, create value over time not only economically but also socially and environmentally, no longer in dyadic perspective (for the property), but in a broader one, defined systemic. The scientific and technological progress, the different forms and structures of markets, innovate strategic actions implemented by competitors, the changing tastes and needs of consumers, a higher standard of living than in the past, the rich sources of information, the spread of culture together with the growing ecological problems and the protection of the natural environment, have led companies to change their decision-making and operational dynamics that distinguish them. In operational terms, there has been a drastic reduction in the degree of specialization hierarchy and a recovery of flexibility. This situation giving broader movement margins to individual macro-components and allowing an independent accumulation of skills, favored the internal design of their routine. In strategic-decision-making, however, more and more companies fit the ethical and social purposes within their constitutional charter of values and strategy they implement. Taking forms of social responsibility, as well as economic, contributes, in fact, to determine the success of creating a climate of consensus both exogenous and endogenous (Fasiello, 2012). This has led to the development of a new prototype of enterprise, the post-Fordist company, whose survival is increasingly linked to the entrepreneurial skills possessed by the entity responsible for its government as well as the capacity and the flexibility inherent in its structure (Golinelli, 2005; Ferrara \& Thomas, 2010). Thus it configures an entity that the business, in order to survive, have to listen every day, distinguished by a strong drive for innovation and a strong will, in order to be at the center of the transformation processes in the industry, rather than being guided by it. For the most cable business organizations, in fact, changes may represent an opportunity to also become the subject of evolutionary change, but be instead a simple object (Cafferata, 2010). To this end, however, it is necessary that the company gives rise to constant innovations to the hardware/technology but also to innovations of a software/organizational management 
(Perrini \& Tencati, 2008). Today the company has to operate in a responsible manner, through sustainable practices oriented to the full protection of natural resources, and to be present where the changes take place, or where customers are, where they originate and consume the business. This requires the development of increasing levels of entrepreneurship and strategic/operational flexibility. Only with radical innovations in this area, or with changes that include a continuous renewal of the logics that underlie its decision-making and production, the company can co-evolve with the reference environment and remain competitive. It must also be proactive in relation to the evolution of the context so as not to jeopardize the legitimacy acquired because of the strategies pursued by competitors. This is especially important today, in an era in which companies, besides having to compete in an increasingly globalized and hyper-competitive world, are facing a severe economic crisis that makes the challenge even more difficult. Based on these considerations, the research question is: "a company operating in a sector in crisis, can create value through a dynamic evolutionary time to perpetuate the development of relations with its stakeholders network anticipating the evolutionary trends of its reference environment?

The paper is structured as follows. After the introduction, we will carry out an analysis of the literature reference about the company regarded as an entity evolving in order to create value. Here we will focus on the company that can represent not only the object but also the subject of evolutionary change. To give substance to the claims of the literature in the third paragraph a case study analyzes the strategies related to the evolutionary dynamics of Renner Italy Spa. It is a company committed to the success of the production of wood coatings in Bologna, which reached in time significant results in terms of value creation.

\section{Research Methodology}

To achieve the goal a methodology of qualitative research based on the case study has been applied, which is considered the most suitable for studying complex phenomena (Eisenhardt, 1989; Yin, 1994; Dubois \& Gadde, 2002). The choice of the company to be analyzed was induced by the results achieved by the Renner Italy that in opposite to the international economic and financial crisis and the difficulties related to the particular sector is that the start-up, in just ten years has managed to grow both in terms of quantity and quality, becoming the fifth most important Italian industry of wood coatings. A thorough analysis of the choices that have enabled it to establish itself, and that the results achieved in the last five years, if consistent with the assertions of the literature, will allow to respond promptly to the research question. Secondary data were obtained through documentary analysis of financial statements recorded in the past five years, the public source and magazine industry.

\section{The Company as "Cell" Evolving in Order to Create Value}

The target for the achievement of profit is not a sufficient condition, even if necessary, to achieve the purposes of the business system of value creation. The company has the ability to perpetuate this magnitude over time. This condition of failure to observe the principle of economy also arises from the awareness that the firm is a "cell", or "a primary agent of broader socio-economic realities (technological world, consumption, banking, finance etc.), a "systems of systems", which performs functions and roles varied, insist on increasingly large geographic areas, showing degrees of fulfillment variations in time with a dynamic evolution that often is brought to emergent processes and spontaneous difficult predictability" (Golinelli, 2009). It is not possible, therefore, study the enterprise system without considering the evolutionary lines of the global context to which it belongs, which is influenced by and influence itself. Where the objectives and strategies, which are the basis of the action of the governing body, are also the result of the spirit of the time in which they are designed. It is good to point out that the governing body, in performing its function, must counter the subjective logic that can lead to the dissolution of the system. In time, however, in relation to its different shape, it has sought to reconcile different interests favoring a profit orientation in dyadic perspective, favoring a distribution of the same in favor of the property. Property that already in the phase before the formation, plays a creative role, which is embodied in the identification of latent needs of the market that have not already found a specific mode of satisfaction or new ways to meet needs already expressed. It makes venture capital that contributes to the formation of an initial endowment of financial means through which the company runs business; is the person who bears the risk in the first place qualifying entrepreneurial activity and defines the structural setting of the governing body, reserving the choice to be part of it or not subjectively. This thesis is supported by Friedman (1962), who believes that "the real social responsibility of the company is to achieve the highest profits - obviously in an open, fair and competitive behavior- producing wealth and work for all as efficiently as possible". This view, however, causes the management to favor the short term objectives ignoring, thus, the needs of the business system, which, as said, has its own ontological autonomy and its own long-term purposes. Also, as a result of these considerations, is a growing awareness that the property is not the only carrier interests to bear the business risk. In fact, if this is likely to be with reference to the remuneration, residually, for the allocated capital, and in case of default by the loss of the same, so also other stakeholders take risks: those that affect the achievement of the strategic objectives of enterprise and those who are 
affected (Freeman \& Reed, 1983; Freeman, 1984; Savage et al., 1991; Clarkson, 1994; Starik, 1994). First of all employees, as it regards the maintenance of employment and remuneration, creditors, the recovery of the capital granted as credit and its remuneration, managers, remuneration, career prospects and not last social prestige, suppliers for payment extensions granted, if any, customers, especially those who have outsourced one or more stages of their production process. Moreover, if a company can not arise except by the effect of the creative impulse of its founder and promoter of the team, cannot be ignored that it needs to draw on a number of external resources, critical for its very existence, that are provided by private and public entities. At the same time, you can not underestimate that the activities and internal processes are made up of individuals and organizational units that actually grow as the time runs, their relational and social logics as well as their special interests (Gatti et al., 2009). Therefore, the company takes the form of a "constellation of interests" to meet, which have the ability to influence its growth and its very existence (Ansoff, 1965; Carroll, 1989; Donaldson \& Preston, 1995).

All these reasons explain the relevance of the Stakeholder's Theory since Evan and Freeman (1988) highlight the "fiduciary relationship" that managers have with a wide range of stakeholders which include, in addition to those specified previously, even the competitors, the local community and "the management in his role as agent of these groups" of stakeholders (Goodpaster, 2007).

Careful management of these relationships enables positive interactions that are increasingly taking the role of real strategic assets, especially in a context in which the supra-systems and sub-systems are characterized by being more viable and demanding. For example include: investors through containment of costs and risks, causing the same to hold the units/shares in the long run, even if they could achieve higher returns by investing in alternative instruments; employees, facilitating the recruitment and retention of the workforce that possesses distinctive skills and knowledge, limiting turnover and encouraging cooperative commitment to the organization; customers, increasing their loyalty to the company; suppliers, mitigating risks associated with their potential unreliability, to redistribute the tasks between organizations for greater efficiency (D'Orazio, 2004). That can result in a further saving of costs with benefits for the area, which increases the level of consensus and social legitimacy of the enterprise. The adoption of this vision is a sort of evolution, the approach of Value Based Management, leading to Stakeholder Management (Freeman, 1984; Clarkson, 1994; Donaldson \& Preston, 1995; Mitchell et al., 1997; Berman et al., 1999; Ogden \& Watson, 1999; Post et al., 2002; Johnson-Cramer et al., 2003; Perrini \& Tencati, 2006; Rusconi, 2012; Carroll \& Buchholz, 2014) and the creation of value in a dyadic perspective to that related to systemic perspective (Golinelli, 2008). Where the creation of value in dyadic view, relegating the expectations other stakeholders, greatly reduces the same chances of survival of the business system because it shrinks viable resources. The second, however, able to assure the consensus and legitimacy it needs, allows to continue to operate in their environment of reference. Properly understood, then, the concept of value creation in a systemic perspective involves the activation of a continuous process of collaboration and co-evolution between enterprise system and system-environment without which it would not be able to survive (Gatti et al., 2009). This results even more true in a complex and unstable context as the current one in which the resources are increasingly distributed among many nodes of a network that works with the indispensable contribution of many units, large and small, each with its expertise and uniqueness (Sanguigni \& Bilotta, 2011).

\section{The Company, the Subject of Evolutionary Change}

Businesses to survive, as well as adapt to the needs of the environment, must initiate projects and self-determined paths. In compete for their survival, also seek to develop from quantitative the point of view instead of remaining at the mercy of environmental perturbations waiting to be adapted; actively seek success. In short, they are also the subject of evolutionary change. Volitional entities, with leadership, highly creative and innovative, are able to make decisions that move the environment and can even change the socio-economic system (Cafferata, 2010). Significant in this regard is the thought of Ceccanti that focuses on the concepts of "natural causality" and "creative causality," meaning the first, the evolution of the company as a result of environmental factors, elusive to the domain of the government body; with the second, the possibility for which the dynamics of the same follows a precise drawing prepared by the decision maker, even in the presence of a high degree of environmental complexity. The company that operates in a given sector, which competes and cooperates with other systems, which holds a bundle of resources (Hamel \& Prahalad, 1996), that "fight" for its very existence, is able to create a kind of "social respect", rooted in the environment that welcomes, lays the foundation for achieving and maintaining a competitive advantage over its competitors and be exemplary for the social system (Cafferata, 2010). This situation implies that regarding factors that undermined the foundations "systemicity", must be activated promptly adaptation actions, processing and / or restructuring in order to revitalize its economic function to prevent other entities are able to take the place, legitimize and occupy the social role: "The achieved" systemicity "is the basic factor of competitiveness, but it makes immortal or unchangeable systems. Struggle for existence, 
selection and adaptation never end" (Cafferata, 2010). In its evolution characterized by moments of development and crisis, adaptation and proactive change, the system of the company has to implement strategies to innovate their products and/or processes in order to be consonant with the context. It's the ability to innovate the main driver of the competition that generates not only a competitive advantage for the company, but it helps to wipe out the competition. For Schumpeter (1942), "this process of creative destruction" is a fatal event that constitutes "the cornerstone of capitalism. At the center of this view shows the crucial role played by the entrepreneur that fostering technological innovation, the change of organization of the production structure, changing the basis of the resources and competencies of the company, the achievement of new sources of supply, the spread of new products, the exploitation of new sectors/markets, promotes the "creative destruction" without the which the company would be destined to succumb. The changes in the buying patterns and lifestyles of consumers, technological obsolescence, increased competition, the internationalization of supply and the need to respond to different market segments customizing its offering, lead companies to expand and upgrade its range of products. Innovation is, in fact, the lever to gain competitive advantages that are the source for value creation and sustainable growth, to preserve and value as one of the key components of the intangible heritage of the company. That factor, which is a driver of business competitiveness, allow to increase the social consensus on the part of the local community, without which it would create a barrier to the consolidation of the company on the territory. Think of the attitudes of assets which the company may choose to take to protect the environment through innovations in both production processes and the products, and involving not only the environmental aspects more closely, but affect the whole business system. To increase the social consensus, then, it is a significant contributor also overall responsibility within which combine economic and social aspects that the company implements operating according to principles of fairness, equity and justice (Davis, 1960; Friedman, 1962; Post, 1978; Davis et al., 1980; Arlow \& Gannon, 1982; Epstein, 1987; Carroll, 1991, Sciarelli, 2005). Where social responsibility is due to the actions of the business system that in making business decisions and plan their strategy, deliberately and constantly, assume obligations towards the community within which it is inserted sharing ethical values. A governing body farsighted, however, must take on socially responsible behavior even under the conditions of economic enterprise. In fact, “... the social costs must in any case be tolerable in the overall budget of the company (on pain of loss of equilibrium) and be considered, in addition to the cost for use of the resources of the community, such as genuine investments for the sustainable growth of the company" (Sciarelli, 2005).

\section{Case Study}

\subsection{Introductory Remarks}

The Renner Italy Spa is a manufacturing company from Bologna, born from the desire of some employees out for restructuring by another, which operates in the field of wood coatings, with a deep environmental purpose. This last aspect associated with the results achieved, in just ten years of operation that put it in fifth place among the most important Italian companies in the industry, have induced authors to deepen the study. Growth in terms of quantity, turnover and profitability, in quality, thanks to the know-how developed in-house, the consensus and social legitimacy inside and outside, confirm that the economic crisis and the difficulties of a start- up can be overcome through effective evolutionary dynamic that allows the achievement of unexpected goals. Indeed, the same difficulties become a tool to assert their superiority, the keys that open the door to success. To all this we must add that taking forms of economic and social responsibility revealed a winning strategy that can reward the company through the achievement of adequate levels of systemic effectiveness, by virtue of greater coherence with current needs expressed from the context.

\subsection{The Company's Evolution over Time}

The company in early 2004 started the production of water-based paints, with very low content of volatile organic compounds, respecting the stringent EU standards on the environment while providing consumers with high yield. In the early years of operation, through significant resources in research (in terms of production facilities, laboratories and especially human resources) in addition to improving the quality and variety of products creates a work environment much more healthy. This strategy draws the interest of big business groups that, supported by the specific demands of customers who require products made using of technologies with low environmental impact, are interested in introducing waterborne finishes, also to meet the constraints of the new European directives which provide for a drastic reduction in pollutant emissions. This causes the governing body to increase, by the end of 2005, the production capacity and the area concerning logistics. The following year, with the acquisition and conversion of "Timava and Tivene", the firm enriches its product range to meet the needs of additional classes of consumers (hobbyists) and, at the same time, strengthen the same production capacity to support the ambitious programs of corporate growth. This investment represents an opportunity to contribute also to the socio-economic exploitation of the territory. During this time, it created a distribution channel, parallel to 
that of the sale to the industries and professionals, which guarantees to reach the final consumers. It is also setting up a network of technical assistance to support consumers in the phase of using products, thus ensuring a high quality product of a close-knit teamwork. A new phase of expansion and development is started in 2007 with the construction of the second production, entirely dedicated to the research, production, and distribution of special wood coatings. This operation allows the Renner Italy SPA to produce their own share of the traditional paints for wood solvent, which is still a significant part of the market, until then purchased by an Italian manufacturer. This choice was induced by the achievement of two objectives: free itself from dependence on the contractor and improving service to customers. With the new plants, in fact, Renner Italy is able to fully meet the demand for polyurethane coatings and support the growth in demand for water-based coatings. It can, thus, look to the future with the knowledge to have an operating structure able to quickly respond to any type of demand and market changes. Thanks to the new aesthetic, the sophisticated system choices, adaptation to safety regulations imposed by the EU guidelines, the new drive is in the forefront compared to similar establishments in the market. The second plant allows the conversion of production from solvent to water with a simple maintenance, and thus to respond quickly and flexibly to market changes without stopping and without negative impacts on the production or on the staff. That of wood coatings market is increasingly characterized by a growing demand for eco-friendly products. On the demand side it is made up of clients for whom the relationship of trust with suppliers is based on a delicate relationship of cost / benefit from conversion that are willing to support, compared the advantages and improvements produced by in their production cycles of a paint rather than another. On the supply side, however, it is extremely competitive, characterized by complex technological product innovation and process and extremely hostile in terms of barriers to entry for new competitors such as independent Renner. This is because, although fragmented in over a hundred manufacturers, is actually ruled by a small number of companies well established by decades of operation, particularly aggressive in terms of financial, structural and relational. Assert itself on this industry, offering a wide range of water-based paints and solvents as well as a large share of the market in products with low environmental impact, means being able to offer higher levels of quality in every respect view. Another important fact, for the analysis of the growth of Renner as the markets served. In early 2007, the markets in which it operates, with dimensions in continuous and constant development, are the Italian, European and Asian. In 2008, the joint venture with the Mexican group Comex, the largest producer of paints in Central and South America allows the company to increase employment levels and the turnover of $24.24 \%$ over the previous year. The Renner so you can sit at the table of the Italian leaders in the industry. With 5\% market share in Italy, is already in the Olympus of the top five most important reality. In 2009 the company's strategy is focused on the coverage of new markets as a result of trade agreements with Dubai, Portugal, China, Tunisia and Europe, paving the way for the penetration in other markets such as Turkey. In Italy, already has business relationships very solid, thanks to the quality and reliability of its products, enabling it to further increase the range of products to meet increasingly sophisticated needs. Great attention is paid by the governing also to increase the level of satisfaction of the employees to whom it is addressed an incentive program implemented through the distribution of $15 \%$ of taxed at $10 \%$.

The engine of this initiative is the desire to involve more employees in the corporate life, encouraging team spirit and increasing the levels of efficiency: if productivity grows there are less waste, less unused resources with more satisfactory results at the level of profitability. 2009 closed with a turnover increase of $3.85 \%$ over the previous year which is in contrast to the total paint market instead a decrease between 20 and $25 \%$. Renner Italy is, in fact, the only one of the large firms to close sales in positive thanks to effective teamwork, the increasing level of exports and coverage of new markets in Eastern Europe is that in Indonesia. These results are due to specific industrial strategies. Renner Italy, invests heavily in research and human resources it has, with which they share the objectives and choices.

As for values, cultivates respect for the environment, the spirit of sacrifice, competitiveness based on product quality and efficiency of services. Ingredients that offer as a virtuous example industrial. To the expansion in Italy, from 2010, the company has added that in foreign territory. Indeed, it has set its facilities across the border in response to asphyxia of the Italian market. Also in this year it invests to increase the level of innovation of its products and influence the choices of customers through a communication original, creative and effective in order to channel outside its industrial identity. Through social media it seeks to understand the needs of customers, gather suggestions and continue to provide useful tools. Aware that the image perceived by the public is never automatically mirrors the real identity of a company, day after day, it invest and work on two-way flows of information, both incoming and outgoing. In the same year the Renner Italy SPA, after a long and complex process, obtained the ISO 9001:2008 for the benefit of customers and suppliers. The performance allow you to acquire major orders from large business realities in is a reputed trader dependable and technologically advanced, able to marry the path of social and environmental responsibility. All this accompanied by an industrial action aimed at 
protecting the environment also with regard to air emissions, is an injection of prestige internationally for corporate image. These performances are supported by the trend of sales in Italy, in the first half of 2010, registering an increase of about $+16 \%$ while foreign competes with a $+27.64 \%$. In the same year the company launches the electronic invoicing employ novel solution InvoiceComm Documents Exchange UniCredit Corporate Banking. The aim is to promote adhesion to the online proposal InvoiceComm for receipt of the invoice electronically that the intention of the promoters, should permanently replace the paper bill, while ensuring reliability, flexibility, simplification and extremely fast data transmission. Less paper means, then, even more respect for the environment and Renner Italy confirms sensitive to eco-themes. In this period the search for Renner Italy implemented in close cooperation with a customer, which obtains exclusive of the new system, there is provided an innovative product for the furnishings that are made of foam rubber, can be coated with non-toxic paints. This seventh year closes with a turnover of 54 million euro that goes beyond the objectives. In 2011, the Company continues to invest in social and cultural activities that affect them, believing the assumption of social responsibility a structural dimension of the life of the company. The responsible attitude must, therefore, also be reflected in terms of investment in activities considered ethically attuned to the company spirit. Also in this year Renner Italy was awarded the "Company to Watch in 2011", or enterprise model in its sector. This recognition is awarded for:

- Got a sales performance above the sector average and a good level EBITDA/revenues;

- Established a leadership position in its industry or in a narrower field of specialization;

- Adopted a business model consistent with the evolution of the industry;

- Conquered one or more points of competitive advantage on the main critical success factors in the field of specialization;

- $\quad$ Acquired a high growth potential in the short and medium period;

- Implemented specific strategies for product innovation or process proved successful or otherwise distinctive with respect to the degree of innovation sector.

Also in this year there was an increase in turnover of $14 \%$ compared to 2010.

In 2012 with the accession to the "European Agreement 20-20-20", for the biennium 2012-2014, the advantage resulting from the political anti-waste is redistributed equally between the company and employees. In addition, employees can benefit from the $15 \%$ of the profits earned in the first year of the agreement and $10 \%$ in the next two years with a fixed amount of 650 euro starting point regardless of the final result. The introduction of this new initiative, entails the involvement of human resources in a virtuous race to reduce energy costs, waste disposal, gas, consumables, etc., whose positive effects are transferred directly into paychecks. In practice: the worker saves resources, the company invests in efficiency and cost benefits are divided in half. So Renner Italy becomes an original experimental laboratory of the principles of environmental and social responsibility.

In 2012, however, the Italian market of paints for wood has broken down. The sales contract and the price of raw materials falls. In the first 90 days of 2012 some 3,000 companies fail. In this gloomy picture, the company, follows two guidelines: the strengthening of principals abroad and maintaining the positions acquired in Italy during his eight years of life, determined to exploit its aggressive and technologically advanced, in terms of trade policy, the provision of products and services. In fact, it continues to innovate and enhance its instruments for sale and is, indeed, even launched in the computer industry, proving once again sensitive to the extraordinary possibilities offered by new technologies. Renner Italy, despite the context present several problems, continues to support with conviction numerous social initiatives.

The company is certainly a reality that does not give up before the economic crisis and the difficulties associated with the start-up. Rather it shows itself strong and determined, able to combine with the social and economic responsibility for this first obtains the mention of the 10 best green reality of the country as part of the Sustainable Development Award. Also results in the Enterprise Environment Award, which is the highest award for Italian companies that have made an innovative contribution in terms of environmental sustainability and social responsibility in the course of carrying out its production activities.

These awards reinforce corporate strategy since it is able to generate added value by interpreting intelligently environmental protection as a competitive factor and development, both on domestic and on international market. Even in 2012 the turnover grew by $11.06 \%$ compared to 2011 supported significantly by exports $(+28.5 \%)$, since national recording a decrease of $3.7 \%$. However, with a market share which stood at $9 \%$, Renner Italy committed 80 distributors for a total of 60 countries and 4 continents served. Russia is the largest buyer, absorbing alone $43.7 \%$ of production destined abroad. Booming even France, Poland, Portugal and England. Nationally, the regions that 
absorb the largest number of products are Veneto, Marche, Piemonte and Emilia Romagna.

In 2013 the approximately 200 employees receive a bonus of $€ 2,150$ (gross, 1,629 net), in recognition for their work. Distribution of profits and benefits resulting from energy saving defend the purchasing power of wages of employees at a time of great difficulty for the Italian economy. It is a 15th month in a company that already in 2004 decided to establish, in a completely autonomous, 14 salaries. With these initiatives are caught simultaneously two benefits:

1) A sense of belonging and the direct involvement of the workforce in the company's mission;

2) The disclosure by media of a clear image of the company, ethically and socially responsible.

These initiatives represent an innovation for the industry by imposing "its gear" even in industrial relations and social responsibility policies, particularly, as said, the environment and salary conditions of employees.

The bonus is also a striking example of how dialogue with employees produces excellent results.

Following the increased demand for products, especially from foreign markets, the Renner Italy SPA performs, in the current year, substantial investments in structural level.

2013 ended with an increase in turnover of around $16 \%$ which is able to double profits over the previous year, allowing the company to reward employees with two additional months.

In 2014 in Italy Renner is introduced "lean thinking" just the Toyota with the project R5S, where R stands for Renner Italy and 5S are the initials of the five Japanese verbs Seiri, Seiton, Seiso, Seiketsu, Shitsuke (select, organize, cleanse, standardize, sustain). The target is to improve continuously through the minimization of waste, increase safety standards, increase the quality of the products, in the right time and with the right efficiency. To all this we must add that the month of June 2014 at the plant in Bologna, productive activity is supported solely by electricity from renewable sources. The plants, in fact, are only powered by hydro, wind, solar and biomass, in order to reduce the polluting impact of the energy system and preserve the environment.

The company, therefore, continues to grow as well as the quality of products and services thanks to the constant commitment to research, innovation, environmental protection and energy saving, satisfaction/well-being of human resources, albeit with a strong tendency to export. As part of the mission and values of Renner Italy is felt "a duty to safeguard the ecosystem" because "we know amaze the beauty around us and we want to contribute to its maintenance", "we believe in the value of people, on this root we elevated our company philosophy on which two fundamental principles are spread: respect and satisfaction ".

\section{Findings and Discussion}

A business system to be effective in its environment requires an operational structure that translates into action the strategic guidelines defined by its governing body. In this task, as a result of significant changes in the context in which the company operates, the operating structure of Renner Italy SPA is delegated not just enforcement activities, but also to activities of an operational decision-making related to problem solving. In organizational perspective, this resulted in a drastic reduction in the degree of specialization and hierarchy, operating within, in a recovery of flexibility. The increased autonomy of individual macro-components has allowed the same to accumulate skills in order to design their own routines internally. This, combined with the recognition of the role of human resources, no longer reduced to the mere operation of a machine, enabling the company from Bologna to perfectly embody the business model of post-Fordist. The results of those choices are gathered in terms of a high rate of innovation of the product portfolio of the company, and, in general, in a more efficient and effective operation of the entire machine.

Overall, the human resources that make up the physical structure of Renner Italy have increased from 135 in 2009 to 194 in 2013. It is a result in contrast to those achieved by other companies operating in the same sector. Suffice it to say that only the laboratory consists of 40 items: about one-fifth of the entire workforce. No company in the industry enjoys numerical relations of this type, a sign of the great importance that the research, the development and, therefore, innovation play in the enterprise. However, remember that a company that is truly responsible life, where "the viability is demonstrated primarily by the profit performance and growth examined on a multi-year period, and at the same time socially oriented, where the social orientation is firstly shown by attention brought to the fulfillment of the legitimate expectations of all stakeholders" (Molteni, 2004). In order to show the results achieved in this regard by the Company examined, the following is an analysis of the main profitability ratios, which are calculated relative to the time span that goes from 2009 to 2013.

As can be seen from Graph 1, the Renner Italy SPA presents a positive economic growing over time. 


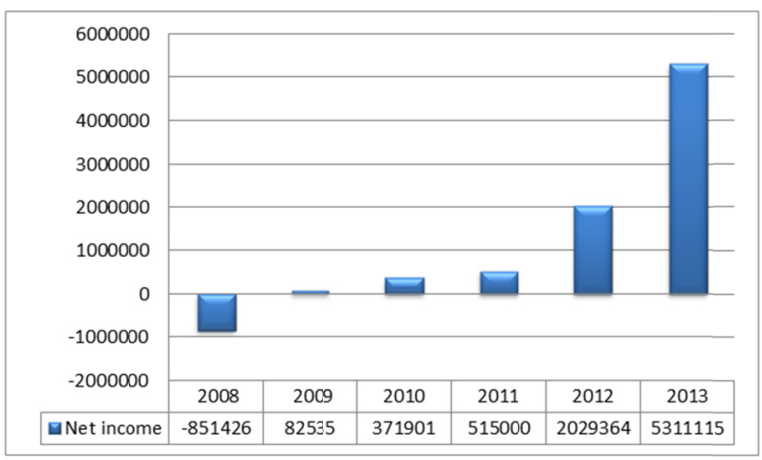

Figure 1. Net income from 2008 to 2013

The break-even point threshold is exceeded for the first time in 2009 with a profit of EURO 82,535. Exceeding the same happens with a year earlier than the already optimistic forecasts of the start-up.

In 2010 net profit reaches 371,901 euros while in 2011 the 515,000 Euros. This year the company is able to close the income statement positively thanks to higher list prices charged on the whole range from the commercial network.

In 2012 the net profit still grows, reaching a height of 2,029,364 euro in a year that saw several competitors out of the market as the relevant Egidio Milesi and Wip Coatings.

2013 closes, finally, with the doubling of profits, increased from 2,029,364 euro in 2012 to 5,311,115 euros. This result is considered excellent for both the current difficulties and because it raises well above the results obtained in recent years by major companies in the industry.

Therefore, a trend that shows the goodness of the choices made by the company and rewards the efforts made by shareholders in the past ten years, more than a cause of great satisfaction for employees, workers, managers and all employees who are committed with enthusiasm for achieving this result.

An analysis of profitability ratios, ROE shows a growing trend significantly improving the projection horizon, reaching above the rates of return on alternative investments at low risk. Considering the year 2013, the difference between the ROE and the rate of return of the BoT of over 32 percentage points (from 33.07 to $0.709=32.361$ ), represents the risk premium that goes to remunerate the property because of the risk to investing their capital in the enterprise.

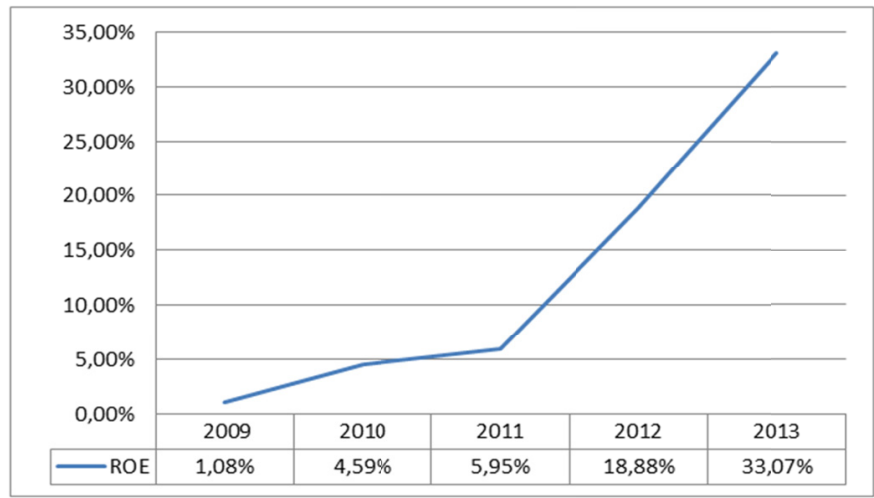

Figure 2. Return on equity 2009-2013

Also ROI is greatly increased from 2009 to 2013 , passing from $11.8 \%$ to $59.31 \%$, thus increasing by as much 47.51 percentage points in just five years. (Keep in mind that in the calculation of the denominator was placed on Invested Capital Operating). A trend that, as written in the financial statements of the company, is in line with the expectations of shareholders and summarizes the effectiveness and the efficiency with which the functions of Renner Italy, engaged in the typical management processes, carrying out their task. 


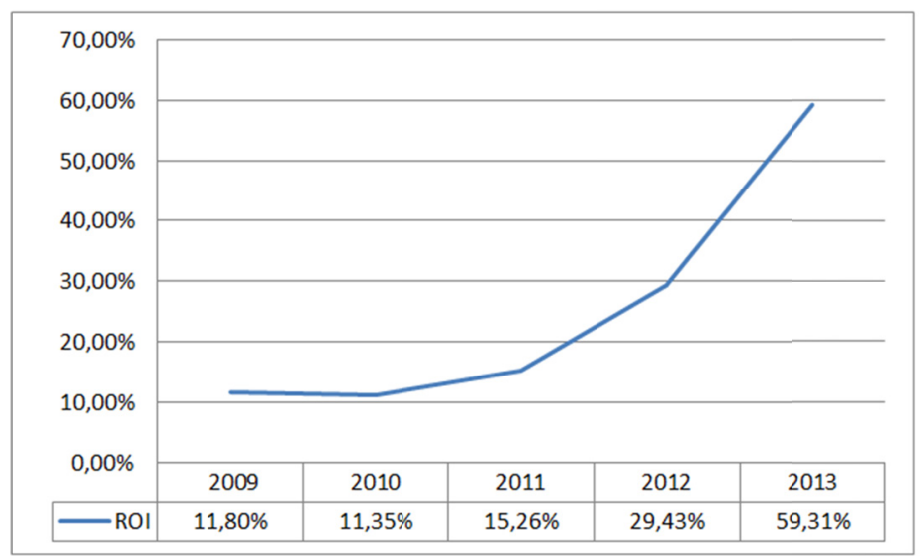

Figure 3. Return on investment 2009-2013

For appropriate interpretation of this index is, however, necessary the comparison with the cost of the average percentage of the money given by the Index of burden of debt capital. From Graph 5 it is clear that the ROI is far greater than the ROE in all the five years, with a peak in 2013. This situation is synonymous with the fact that the company is creating wealth through the complex of the investments made in the activity feature, improving from year to year that capacity.

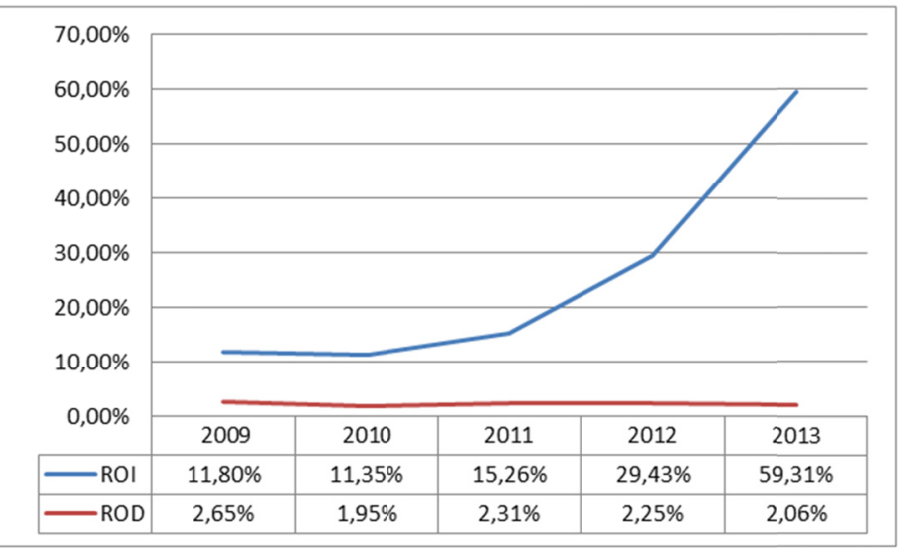

Figure 4. Comparison of ROI and ROD

As for the Index of indebtedness, the analysis shows an increasing trend between 2009 and 2012, the year in which it has been recorded the highest value, which rose from 5.96 to 6.89 , and then fall in 2013 to 6.38. The company in fact is much indebted. This is due to the use of short-term bank to finance the investments and the assets related to the strong increase in sales. In 2010, then, inventories increased due to the increase in stocks of strategic raw materials as a result of a choice made by the company in order to protect themselves from their scarcity in the market and the strong tension in the prices. In 2012 Renner makes a strategic shift in debt to long-term significantly reducing its debt in the short and in general the overall debt. Thus it starts a recovery phase where asset / financial balance which result to be better than expected results from the Multi-year Plan 2011-2015 prepared by the Company. The reduction index (increased from 6.89 to 6.38) which occurred in 2013, confirms this improvement, which is again much higher than expected. This has been made possible by the expected profitability and the investment slowdown occurred after the completion of the start-up of the company. However, just in front of a leverage ratio as high as it can enjoy the positive effects of leverage, being the ROI higher than $\mathrm{ROE}$ in all the years considered. 


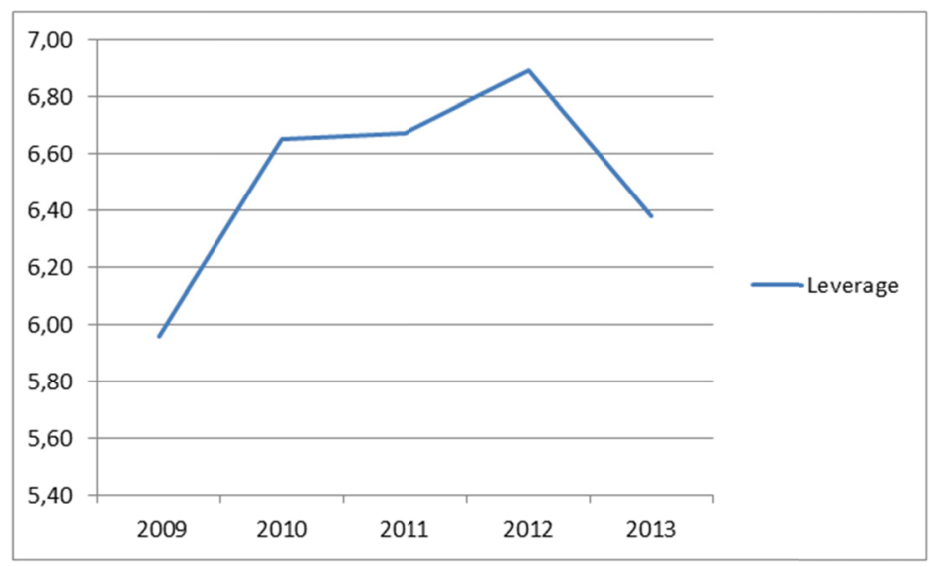

Figure 5. Index of debt from 2009 to 2013

Economic success is still closely linked to the originality and innovativeness of the strategic and operational choices undertaken by the WTO governance examined. In particular, the research and innovation of new products and new processes the real engine of Renner Italy, based on the knowledge that the pressing instances regulations regarding the environment and the growing demand for eco-friendly products, lead to consider production of water-based coatings market of the future. As reported in the following graph, in all five years considered the company has released a number of new water-based products, which represent the core business, always greater than that of the new solvent-based products, with an average of 500 new water based products per year and 400 new solvent-based products.

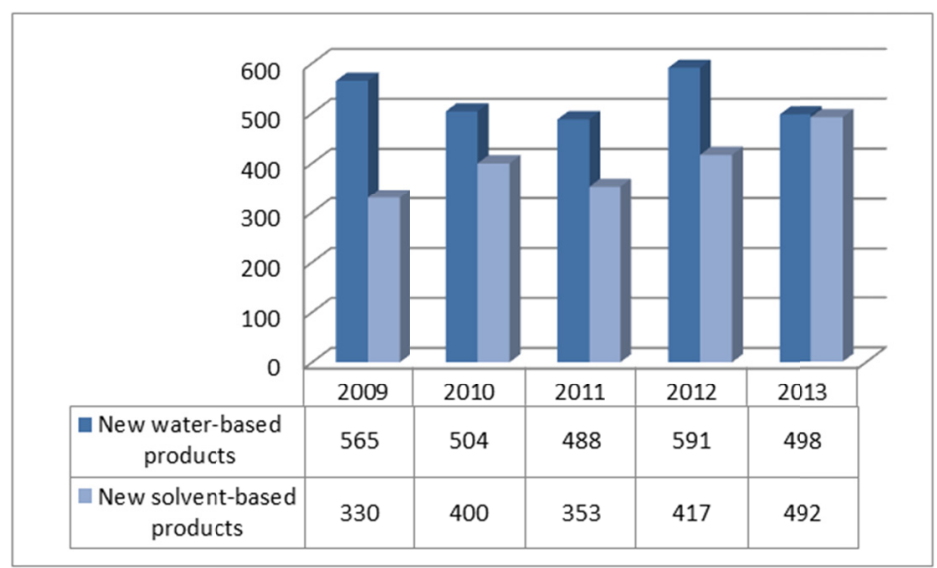

Figure 6. New products placed on the 2009-2013 market

The innovation is confirmed by Renner Italy SPA engine for development and own strength, the means by which it is not only the object but also the subject of evolutionary change.

\section{Conclusions, Managerial Implications, Limitations of the Research and Insights for Future Research}

An entrepreneurial organization which would lead to a passionate and safe route is able to adapt to the changing environment, while the more skilled can anticipate them, becoming the subject of evolutionary change. Renner Italy SPA is a fine example of how to succeed in this enterprise. The company that has the size and multinational interests is successful, in fact, to make their way in the context highly competitive and complex, for technological innovation of products and processes and extremely hostile in terms of barriers to access for new independent competitors like Renner Italy SPA. This is because, although fragmented in over a hundred manufacturers, is actually ruled by a small number of companies well established by decades of operation and particularly aggressive in terms of financial, structural and relational. The Company has chosen to be the master of its own 
destiny, perfectly embodying the features of the post-Ford enterprise. It chose to listen context every day distinguishing by a strong drive for innovation and a strong will to be the center of its own transformation processes, rather than be guided by changes in the environment. It chose a new system of government that focuses on the man and his dignity, but also the environment and the preservation of its resources. So that's cause the birth of a project whose implementation involves all, internal and external parties, with the passion and the love put as part of a big "family". This vision has enabled it to create value not just in dyadic perspective, but in a broader one, as well as systemic: the new big imperative for companies of our time. In particular, the positive atmosphere that the governing body has built allows Renner Italy to benefit from the positive interactions activated with employees, who now constitute a real strategic asset for the company.

The Renner Italy SPA, thus, has become over time a real "excellent" company that despite the difficulties of the international context develops energy saving strategies, part of the dividends distributed to employees, continues to improve their economic performance and to recruit human resources. The deserve of this falls on the government body that, with tenacity, determination, courage and vision, made of the same economic crisis a strong point, aware that difficulties can represent not only a threat but also an opportunity. As summary of the study it can be concluded that the success of the Company examined derives from having entered for ethical and social concerns into their strategies evolving in line with the requests and trends of the current socio-economic context in which it operates.

Taking an economic but also social responsibility enables it not only to survive, but to improve day by day its systemic effectiveness and, thus, create increasing value levels. Therefore, the research question can be considered verified as a company while belonging to a sector in crisis may create sufficient levels of value through an evolutionary dynamics to anticipate the trends of its environment of reference.

This work, however, is not without limits due to the methodological approach used. The case study, in fact, does not allow to generalize the results. However, a subsequent search on the values, strategies and behaviors taken by a panel of firms operating in this sector could further confirm the findings. The start of this study, which represents a possible path for future research, would fill the inevitable limitations of the presentation of a single case.

The conclusion reached, however, gives important insights for the parties responsible of management. They should raise awareness that the firm is in itself an evolutionary system that to survive requires a constant renewal of its structure, its strategy, its way of facing the future, where the involvement and sharing of objectives with human resources who work every day to the realization of its life is necessary. To remain anchored to the old logic would mean losing ground to competitors also coming to the dissolution of the system. In other words, a company can only survive by innovating continuously itself, in a manner consistent with the values deemed relevant by the community, because if it remained motionless in their structures and in their strategies, sooner or later perish for failure to meet the cost of long period. All that would be generated as a result of the loss of social consensus and vital contributors to the benefit of other organizations with which it is competing on the market. If the environment evolves, the company must evolve with it.

\section{References}

Ansoff, H. I. (1965). Corporate strategy. New York: McGraw Hill.

Arlow, P., \& Gannon, M. J. (1982). Social Responsiveness, Corporate Structure, and Economic Performance. Academy of Management Review, 7(2), 235-241. http://dx.doi.org/ 10.5465/AMR.1982.4285580

Berman, S., Wids, A., Kotha, S., \& Jones, T. (1999). Does stakeholder orientation matter? The relationship between stakeholder management models and firm financial performance. Academy of Management Journal, 42, 488-506.

Cafferata, R. (2010). L'impresa che diventa sistema: Una lettura nel duecentenario darwinian. Sinergie, 81, 51-76.

Carroll, A. B. (1989). Business and society: Ethics and stakeholder management. Cincinnati, OH: South-Western.

Carroll, A. B. (1991). The pyramid of corporate social responsibility: Toward the moral management of $\begin{array}{lllll}\text { organizational stakeholders. } & \text { Business } & \text { Horizons, } & 34(4), & 39-48 .\end{array}$ http://dx.doi.org/10.1016/0007-6813(91)90005-G

Carroll, A., \& Buchholz, A. (2014). Business and Society: Ethics, Sustainability, and Stakeholder Management. Cengage Learning. 
Clarkson, M. (1994). A Risk Based Model of Stakeholder Theory. Proceedings of The Second Toronto Conference on Stakeholder Theory. Toronto: Centre for Corporate Social Performance \& Ethics, University Of Toronto.

D'orazio, M. (2004). Gestione Degli Stakeholders, Assets Intangibili E Leadership Etica. Notizie Di Politeia, 20, 74.

Davis, K. (1960). Can Business Afford to Ignore Social Responsibilities? California Management Review, 2, 70-76. http://dx.doi.org/10.2307/41166246

Davis, K., Frederick, W., \& Blomstrom, R. (1980). Business and Society: Concepts and Policy Issues. New York: Mcgraw-Hill.

Donaldson, T., \& Preston, L. E. (1995). The Stakeholder Theory of the Corporation: Concepts, Evidence, and Implications. Academy of Management Review, 20, 65-91. Http://dx.doi.org/10.5465/AMR.1995.9503271992

Dubois, A., \& Gadde, L. E. (2002). Systematic Combining: An Abductive Approach to Case Research. Journal of Business Research, 55, 553-560. Http://dx.doi.org/10.1016/S0148-2963(00)00195-8

Eisenhardt, K. M. (1989). Building Theories from Case Study Research. Academy of Management Review, 14(4), 532-550. Http://dx.doi.org/10.2307/258557

Epstein, E. M. (1987). The Corporate Social Policy Process and The Process of Corporate Governance. American Business Law Journal, 25(3), 361-383. http://dx.doi.org/10.1111/J.1744-1714.1987.Tb00508.X

Evan, W., \& Freeman, R. E. (1988). A Stakeholder Theory of Modern Corporation: Kantian Capitalism. In T. Beauchamp, \& N., Bowie (Eds.), Ethical Theory and Business (pp. 38-48). Englewood Cliffs, NJ, Prentice Hall.

Fasiello, R. (2012). Funzione Sociale Delle Imprese O Imprese Socialmente Responsabili? Profili Etici Ed Economico-Aziendali. Impresa Progetto-Electronic Journal of Management, 2, 1-33.

Ferrara, G., \& Thomas, A. (2010). Evoluzione E Divenire Della Funzione Imprenditoriale Nella Dottrina Aziendalistica. Rirea Aziende, N. 1.

Freeman, R. E. (1984). Strategic Management: A Stakeholder Approach. Boston: Pitman.

Freeman, R. E., \& Reed, D. L. (1983). Stockholders and Stakeholders: A New Perspective on Corporate Governence. California Management Review, 25(3), 88-106.

Friedman, M. (1962). Capitalism and Freedom. Chicago: Chicago University Press.

Gatti, M., Biferali, D., \& Volpe, L. (2009). Il Governo Dell'impresa Tra Profitto E Creazione Di Valore. Sinergie, 79, 145-179.

Golinelli, G. M. (2005). L'approccio Sistemico Al Governo Dell'impresa. L'impresa Sistema Vitale. Padova: Cedam.

Golinelli, G. M. (2008). L'approccio Sistemico Al Governo Di Impresa.Verso La Scientificazione Dell'azione Di Governo. Padova: Cedam.

Golinelli, G. M. (2009). L'approccio Sistemico Vitale: Nuovi Orizzonti Di Ricerca Per Il Governo Dell'impresa. Sinergie, 80, 16-22.

Hamel, G., \& Prahalad, C. K. (1996). Competing for the Future. Boston, MA: Harvard Business School Press.

Goodpaster, K. E. (1991). Etica D’Impresa E Analisi Degli Stakeholder. In E. R., Freeman, G., Rusconi, \& M., Dorigatti (Ed.), Teoria Degli Stakeholder (pp. 80-99). Franco Angeli, Milano,

Johnson-Cramer, M., Berman, E., Shawn, L., \& Post, J. E. (2003). Re-Examining The Concept Of 'Stakeholder Management. In J., Andriof, S., Waddock, B., Husted, \& Rahman, S., (Eds.), Unfolding Stakeholder Thinking 2: Relationships, Communication, Reporting And Performance (Vol.17, pp. 145-161). Sheffield, UK: Greenleaf.

Mitchell, R. K., Agle, B. R., \& Wood, D. J. (1997). Towards A Theory of Stakeholder Identification and Salience: Defining the Principles of Who And What Really Matters. Academy of Management Review, 22(4), 853-886. Http://dx.doi.org/10.2307/259247

Molteni, M. (2004). ResponsabilitÀ Sociale E Performance D'impresa. Per Una Sintesi Socio-Competitiva. Milano: Vita E Pensiero. 
Ogden, S., \& Watson, R. (1999). Corporate Performance And Stakeholder Management: Balancing Shareholder And Customer Interests In The U.K. Privatized Water Industry. Academy of Management Journal, 42, 526-538. http://dx.doi.org/10.2307/256974

Paci, I. (2003). Il Contributo Della Dottrina Italiana Agli Studi Sul Governo Delle Organizzazioni Imprenditoriali. Sinergie, 61-62.

Perrini, F., \& Tencati, A. (2006). Sustainability and Stakeholder Management: The Need for New Corporate Performance Evaluation and Reporting Systems. Business Strategy and the Environment, 15(5), 296-308. Http://dx.doi.org/10.1002/Bse.538

Perrini, F., \& Tencati, A. (2008). La ResponsabilitÀ Sociale D'impresa: Strategia Per L'impresa Relazionale E Innovazione Per La SostenibilitÀ. Sinergie, 77, 23-43.

Post, J. E. (1978). Corporate Behavior and Social Change. Reston, VA: Reston Publishing.

Post, J. E., Preston, L. E., \& Sachs, S. (2002). Redefining the Corporation-Stakeholder Management and Organizational Wealth. Stanford: Stanford University Press.

Rusconi, G. (2012). Alcune Riflessioni Sui Recenti Sviluppi Dello Stakeholder Management: Il "Valore Per Gli Stakeholder". Impresa Progetto Electronic Journal of Management, 1, 1-22.

Sanguigni, V., \& Bilotta, A. (2011). Le Reti Come Schema Interpretativo Per Veicolare La Conoscenza E Governare La Complessit ̇̀. L'Industria, 2, 355-371.

Savage, G. T., Nix, T. V., Whitehead C. J., \& Blair J. D. (1991). Strategies for Assessing and Managing Organizational Stakeholders. Academy of Management Executive, 5(2), 61-75. Http://dx.doi.org/10.5465/AME.1991.4274682

Schumpeter, J. A. (1942). Capitalism, Socialism, and Democracy. New York: Harper \& Row.

Sciarelli, S. (2005). L’Ampliamento Della ResponsabilitÀ Sociale Dell'Impresa. Sinergie, 67, 35-43.

Starik, M. (1994). Essay By Mark Starik: Reflections On Stakeholder Theory. Business \& Society, 33, 82-131.

Yin, R. K. (1994). Case Study Research, Applied Social Research Methods Series. Sage Publications, Thousand Oaks, London - New Delhi.

\section{Copyrights}

Copyright for this article is retained by the author(s), with first publication rights granted to the journal.

This is an open-access article distributed under the terms and conditions of the Creative Commons Attribution license (http://creativecommons.org/licenses/by/3.0/). 